Bentham OPen $\quad$ The Open Civil Engineering Journal

RESEARCH ARTICLE

\title{
Decision-making Support Systems Using Case-based Reasoning for Construction Project Delivery Method Selection: Focused on the Road Construction Projects in Korea
}

\author{
Yousang Yoon ${ }^{1}$, Jinho Jung ${ }^{2, *}$ and Changtaek Hyun ${ }^{2}$ \\ ${ }^{I}$ Corporation PMPgM, Seoul, Korea \\ ${ }^{2}$ Department of Architectural Engineering, University of Seoul, Seoul, Korea
}

Received: March 17, 2016

Revised: May 24, 2016

Accepted: May 24, 2016

\begin{abstract}
The decisions on the project delivery method when conducting a construction project are an important part of the process and can heavily influence the success or failure of the project. Many factors have to be considered, however, in determining the project delivery method, and there are no definite criteria. This ambiguity can cause much difficulty. As such, this paper proposes a system based on case-based reasoning (CBR) that supports the decision-making for project delivery method selection considering the future construction project performance. The research was conducted with focus on the road construction case dataset. Based on this, the proposed decision-making support system was devised by applying decision tree (DT) analysis, the effectiveness of selecting a project delivery method for the project performance index (ESDPI), and CBR. This system can consider not only the project delivery method but also the later construction project performance, and can thus effectively support the owner's decision-making.
\end{abstract}

Keywords: Case-based reasoning, Data mining, Decision tree, Project delivery method, Project performance, Road construction.

\section{INTRODUCTION}

The South Korean government has applied a variety of project delivery methods, such as design-bid-build (DBB), design-build (DB), alternative tender, criteria package technical proposal (CPTP), and detailed design technical proposal (DDTP), with focus on large construction projects. It is prescribed that the project delivery methods of large public construction projects in South Korea are determined after due consideration by the Central Construction Technology Deliberation Committee before the preliminary design (after CPTP, DDTP, and alternative tender), in accordance with the "Standards for Large-Scale Construction Bidding Methods" of the Ministry of Land, Infrastructure, and Transport (MLIT) Notice No. 2015-623. Accordingly, the owner selects the project delivery method by himself or herself for the filing of an application for deliberation, when many factors need to be taken into account. Much time is required, and therefore, many difficulties arise [1]. Moreover, as the evaluation criteria for selecting the project delivery method are not quantitative, it is not easy to predict the results before the application is submitted for deliberation. In addition, as there is currently a lack of procedures that take into consideration the performance of the construction project after the selection of the project delivery method, it is difficult to predict the later project performance due to the selected project delivery method. If the owner can compare the performance of the project delivery method and that of similar cases in the past based on the quantitative factors when deciding the construction project delivery method, it will become possible to know which project delivery method is most effective in certain applications or situations. At present, the project performance, business efficiency, and ripple effects of construction projects with a total construction cost of more than 30 billion won are being evaluated based on the "Construction Post-Evaluation Enforcement Guidelines," and the data regarding the performance of a facet of large construction projects in South Korea have been

\footnotetext{
* Address correspondence to this author at the Department of Architectural Engineering, University of Seoul, Seoul, Korea; Tel: +82 2 6490 5577; E-mail: jjh5661@uos.ac.kr
} 
collected in the "Construction CALS (Continuous Acquisition \& Lifecycle Support) Portal System." As the project performance, business efficiency, and ripple effects specified in the post-evaluation data sheet are results that have been derived after the selection of the project delivery method, the construction project post-evaluation reports can be effectively utilized in the process of selecting the project delivery method.

The case-based reasoning (CBR) technique is a method that is utilized to solve new problems by adopting solutions that were used to solve old problems [2]. The CBR technique has been applied in various fields of the construction industry, such as in construction risk management, preliminary cost estimation, and project delivery method selection models. The studies related to the selection of the project delivery method using CBR include a study on finding similar contract methods by classifying the factors that influence the selection of the contract method [3], a study on the methods of determining the criteria for selecting the project delivery method using CBR [4], and a system-related research to select the most profitable bidding method based on the analysis of cases from the two aspects of completion and risk with respect to the bidding method selection [5]. Likewise, previous studies focused only on the delivery and bidding contract method selection results in relation to the decision-making support. There have been few studies, however, on the consideration of the project performance after the selection of the project delivery method and the operational status after the completion of the construction. If the project performance after the selection of the project delivery method is considered, along with the project delivery method selection results, it is possible to compare the effects of the selected project delivery method, thereby helping support more effective decision-making.

This paper, therefore, seeks to propose a decision-making support system using the CBR technique for construction project delivery method selection, one that is suitable for the application of the "Standards for Large-Scale Construction Bidding Methods," based on the collection and analysis of past large construction project cases summarized through the post-evaluation system of construction works. In this study, the decision-making support CBR system was configured with respect to road construction cases, including bridges and tunnels, among the cases collected from the Construction CALS Portal System through the construction post-evaluation scheme. The procedures of this paper are outlined in Fig. (1).

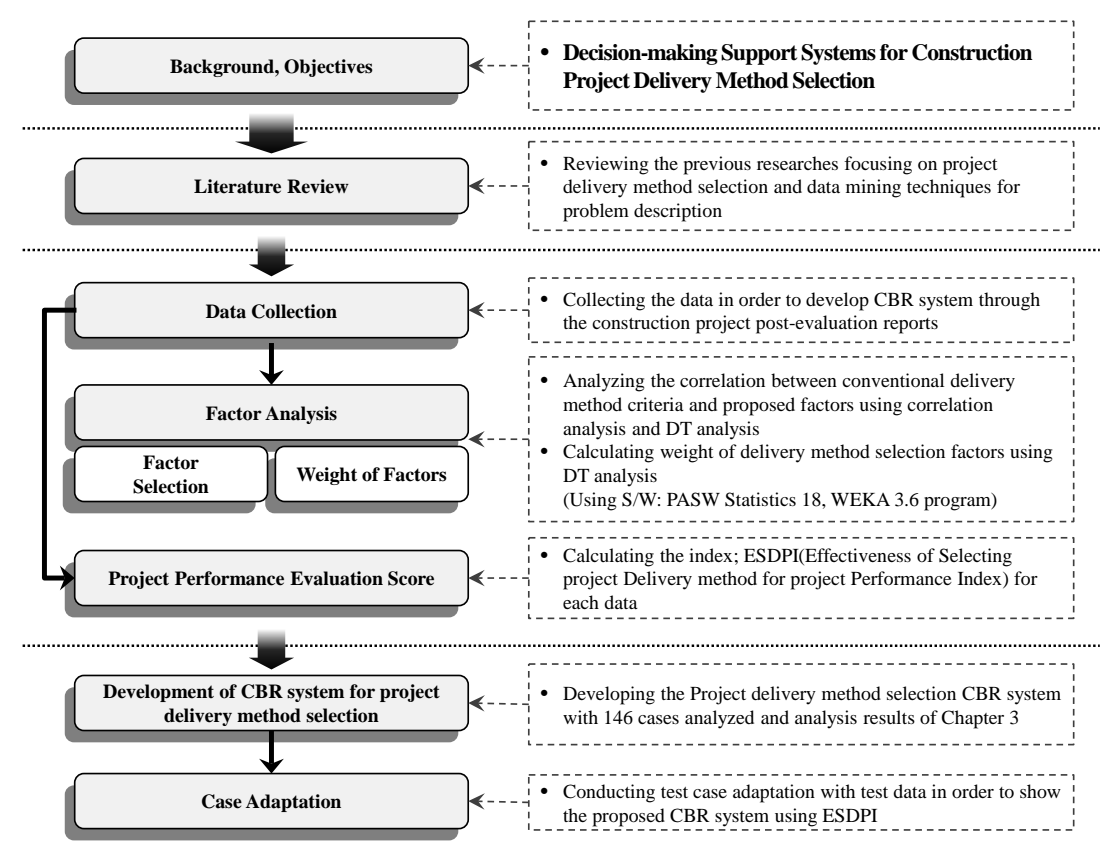

Fig. (1). Research framework.

\section{LITERATURE REVIEW}

\subsection{Selection of the Construction Project Delivery Method}

The selection of the project delivery method constitutes a crucial decision point when establishing a plan for a construction project because the performance of the construction project depends on the selected project delivery method [6]. Reflecting the importance of the delivery method, the past research on construction project delivery 
methods focused on establishing selection criteria and procedures. A previous study derived weights for different selection criteria for project delivery methods using the analytic network process (ANP) method, and proposed a project delivery method selection model consisting of four phases: the preparation, evaluation, decision-making, and action phases [6]. Other studies include one that analyzed the characteristics of large public building projects and identified the factors affecting the project delivery system selection criteria [7], a study that proposed a link between project delivery method selection models and performance evaluation models [8], and a study that analyzed and identified the factors affecting the project delivery method selection criteria and examined the significance of each reference factor [1,9]. The project delivery method selection criteria proposed by previous studies through the analysis of such factors include quality, construction period, cost, complexity, project scale, owner's experience, innovative technologies, and uncertainty. Likewise, the past studies on the selection of the project delivery method mainly dealt with the evaluation methods and criteria required for selecting the project delivery method to be used (Table 1).

Table 1. Previous studies of construction project delivery method.

\begin{tabular}{|c|c|c|}
\hline Writer & Summary & Topic \\
\hline $\begin{array}{l}\text { Kim et al. } \\
(2000)[7]\end{array}$ & $\begin{array}{l}\text { This study developed selection criteria for the delivery system in large public building } \\
\text { projects through questionnaires and interviews. }\end{array}$ & $\begin{array}{l}\text { Project delivery method selection criteria } \\
\text { proposal }\end{array}$ \\
\hline $\begin{array}{l}\text { Hyun and Seo } \\
(2003)[6]\end{array}$ & $\begin{array}{l}\text { This study presented the development of the project delivery system selection model } \\
\text { frame considering the project characteristics and construction environment. }\end{array}$ & $\begin{array}{l}\text { Project delivery method selection model } \\
\text { proposal }\end{array}$ \\
\hline $\begin{array}{l}\text { Yu and } \mathrm{Kim} \\
(2007)[8]\end{array}$ & $\begin{array}{l}\text { This study proposed a project delivery system evaluation model for public } \\
\text { construction projects. }\end{array}$ & $\begin{array}{l}\text { Project delivery method evaluation model } \\
\text { proposal }\end{array}$ \\
\hline $\begin{array}{l}\text { Lee and Kim } \\
(2009)[10]\end{array}$ & $\begin{array}{l}\text { This study proposed an improvement idea for the performance-based project delivery } \\
\text { system (PPDS) based on the analysis of the client's role. }\end{array}$ & $\begin{array}{l}\text { New project delivery method proposal, with } \\
\text { focus on performance }\end{array}$ \\
\hline $\begin{array}{l}\text { Choi et al. } \\
(2009)[1]\end{array}$ & This study presented selection criteria for delivery systems by business type. & $\begin{array}{l}\text { Project delivery method selection criteria } \\
\text { proposal }\end{array}$ \\
\hline $\begin{array}{l}\text { Lee and Jung } \\
\text { (2011) [11] }\end{array}$ & $\begin{array}{l}\text { This study compared the characteristics of each project delivery system (DB, DBB, } \\
\text { etc.) by analyzing quantitative data. }\end{array}$ & $\begin{array}{l}\text { Comparison of the performances of different } \\
\text { types of project delivery system }\end{array}$ \\
\hline $\begin{array}{l}\text { Kim et al. } \\
(2015)[9]\end{array}$ & $\begin{array}{l}\text { This study analyzed and presented the key factors affecting the selection of the } \\
\text { procurement method in public construction projects. }\end{array}$ & $\begin{array}{l}\text { Proposal of criteria for project delivery } \\
\text { method selection }\end{array}$ \\
\hline
\end{tabular}

Despite the huge influence of the selected delivery method, however, on the performance of a construction project, there have been few studies on the methods of utilizing the construction project performance in the process of the project delivery method selection. The previous studies related to project performance include a study that analyzed project delivery methods and proposed a new delivery method called "performance delivery method" [10], and a study that compared the performances of different project delivery methods [11]. These studies, however, did not deal with the utilization of the construction project performance in the selection of the project delivery method. In this regard, this paper seeks to present a decision-making system for project delivery method selection utilizing the construction project performance in the early stage of the project.

\subsection{Data Mining Using Artificial Intelligence Technique}

Using the evaluation results of the performance of a construction method after project delivery method selection requires an analysis of the accumulated data. Most of the previous studies on the selection of the project delivery method in the construction sector analyzed the accumulated data using traditional statistical techniques. Such methodology, however, is limited in that the results will vary slightly depending on how the statistical hypotheses are defined, such as the generalizations of the required data [12]. Conversely, relatively objective values can be derived by analyzing the data using the artificial intelligence (AI) technique through data mining, because this method derives analysis results based on the accumulated data through machine learning, without resorting to statistical hypotheses. Data mining is an effective technique capable of deriving hidden information from a vast amount of data using the key elements of machine learning. Data mining tools allow researchers to predict future trends based on the accumulated data, and support the making of practical business decisions [13].

CBR is an AI technique that supports effective decision-making by identifying similar examples based on past data. $\mathrm{CBR}$ is designed to address new issues using information and knowledge by referring to similar past cases. CBR is based on the psychological theory of human reasoning, which focuses on human psychology solving current issues based on similar past experiences [14]. The CBR technique has found application in a wide range of areas. The past research on the CBR technique covered evaluation models that support bid decision-making [5], project delivery method selection [4], or decision-making on construction contracts [3]. Other studies include a study on the CBR model 
that predicts the possible defect risks during construction [15], a study on the prediction of construction project costs by applying the CBR technique [16], and a study on the use of the CBR model for predicting the project period of building construction projects [17]. Through these studies, the CBR technique found application across the construction industry at large. One of the most crucial procedures for the CBR technique is determining the weight of each of the factors used to calculate the degree of similarity. Most of the studies that applied the CBR technique in a construction project, however, posed limitations caused by statistical assumptions due to the application of the traditional statistical techniques in the calculation of the degree of similarity (Table 2), but these limitations can be overcome by utilizing the weight calculation method among the existing data-mining techniques.

Table 2. Previous studies that used the case-based reasoning (CBR) technique in the construction field.

\begin{tabular}{|c|l|l|}
\hline Writer & \multicolumn{1}{|c|}{ Application scope } & \multicolumn{1}{|c|}{ Method of calculating weights of factors for similarity } \\
\hline $\begin{array}{c}\text { Chua et al } \\
(2001)[5]\end{array}$ & Construction project bid decision-making & $\begin{array}{l}\text { AHP through a questionnaire } \\
\text { (The data-mining technique was not used.) }\end{array}$ \\
\hline $\begin{array}{c}\text { Luu et al } \\
(2005) \text { [4] }\end{array}$ & Construction project procurement selection decision-making & $\begin{array}{l}\text { Statistical technique using a questionnaire } \\
\text { (The data-mining technique was not used.) }\end{array}$ \\
\hline $\begin{array}{c}\text { Chua et al } \\
(2006)[3]\end{array}$ & Construction project contract strategy formulation & $\begin{array}{l}\text { AHP using a questionnaire } \\
\text { (The data-mining technique was not used.) }\end{array}$ \\
\hline $\begin{array}{c}\text { Goh and Chua } \\
(2009) \text { [15] }\end{array}$ & Construction project hazard identification & $\begin{array}{l}\text { Correlation analysis \& assumption using a semantic network } \\
\text { (The data-mining technique was not used.) }\end{array}$ \\
\hline $\begin{array}{c}\text { Ji et al } \\
(2012) ~[16]\end{array}$ & Construction project preliminary cost estimation & $\begin{array}{l}\text { Principle component analysis, multiple regression analysis } \\
\text { (The data-mining technique was not used.) }\end{array}$ \\
\hline $\begin{array}{c}\text { Jin et al } \\
(2015)[17]\end{array}$ & Construction project preliminary duration & $\begin{array}{l}\text { Regression analysis } \\
\text { (The data-mining technique was not used.) }\end{array}$ \\
\hline
\end{tabular}

The AI techniques based on data mining that can calculate the weights of the factors are the artificial neural network (ANN) and decision tree (DT) analysis techniques. DT analysis offers the benefit of deriving results through machine learning using a relatively small amount of data $[18,19]$. The DT analysis technique involves the construction of a decision tree based on the information gain of each attribute of past datasets, without resorting to statistical hypotheses. Therefore, if the information gain is set as the weight of the similarity factor by utilizing it in the CBR technique, more objective results can be obtained.

In light of the above, this study sought to establish a decision-making support system that supports project delivery method selection using the analysis results derived using the two AI techniques DT analysis and CBR, unlike the previous studies that used the traditional statistical techniques.

\section{METHODOLOGY AND DATA ANALYSIS}

\subsection{Case-based Reasoning for Selecting the Construction Project Delivery Method}

The CBR framework proposed in this study is largely composed of three stages: (1) Case Representation; (2) Retrieval of Cases; and (3) Case Adaptation. First, the construction project post-evaluation reports of previously carried out construction projects are collected from the past-project post-evaluation report pool. Second, in the case representation stage, the attribute weights for similarity evaluation are derived from the dataset collected through information gain analysis (DT analysis), and the effect of the project delivery method decision on the project performance is derived and summarized in each case. Third, for the case retrieval stage, the similar projects are retrieved from the collected cases, and the effects of the project delivery methods and the decisions thereon for similar construction projects on the project performance are used to select a project delivery method. Finally, a post-evaluation of the construction project is conducted, and the evaluation report is stored in the past-project post-evaluation report pool. The CBR system proposed in this study was designed to support the decision-making at the project delivery method stage through the procedure shown in Fig. (2). 


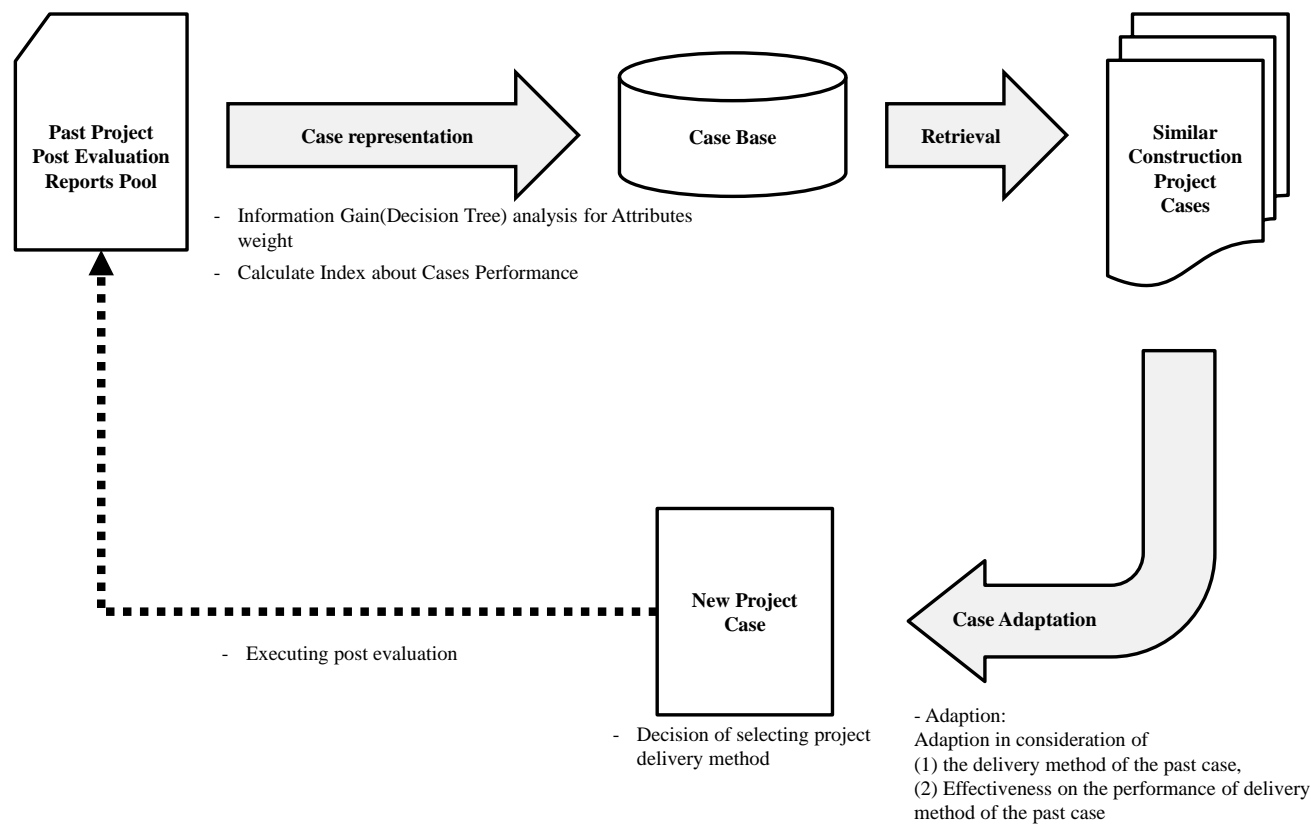

Fig. (2). CBR for selecting the construction project delivery method process.

\subsection{Data Collection}

The construction project post-evaluation reports were analyzed and utilized to establish the CBR system for supporting the project delivery method selection for large-scale construction projects. The construction project postevaluation is a scheme designed to evaluate the performance of a public construction project, and to help improve the efficiency of public construction projects by using the evaluation results for other similar projects in the future. In South Korea, the performance data, project delivery method, and project information of large-scale construction projects with a total construction cost of more than 30 billion won are stored in the Construction CALS Portal System. The Construction CALS Portal System is being operated in accordance with the MLIT's "Construction Work PostEvaluation Enforcement Guidelines" to make it convenient for public clients to implement their construction projects in terms of the construction project post-evaluation reports and others. Summaries of the projects and their postcompletion/operation performance compared with the project plans can be collected from among the construction project post-evaluation reports stored in the system. The construction project post-evaluation reports on 146 road construction cases, including bridges and tunnels, were collected and used as data for building a decision-making support system for project delivery method selection.

\subsection{Selecting the Factors to be Considered for Project Delivery Method Selection}

\subsubsection{Step 1: A Survey on the Quantitative Factors Affecting the Project Delivery Method Selection}

Implementing a CBR system capable of supporting the decision-making on the project delivery method requires a dataset from past construction projects. In addition, the similarity factors to be used to retrieve the desired information after building the dataset should be selected. Based on the degree of similarity, the selected factors are used to find the most similar cases when retrieving the data. As the purpose of this study was to aid the decision-making regarding the project delivery method, the construction project post-evaluation reports of previous construction projects were analyzed, and a number of annual social indicators, including the real GDP growth rate, were collected to build a dataset containing the information on project delivery methods. Thus, independent factors that affect project delivery method selection were derived from it. The project delivery methods selected for large-scale projects in South Korea, however, are decided based on the "Standards for Large-Scale Construction Bidding Methods" (MLIT Notice No. 2015-623). Therefore, it cannot be ascertained if the factors derived above hold any relevance with the standards. The evaluation items for the project delivery method selection considered in the deliberation process proposed by previous studies $[1,6,8,9,20]$ are as follows: owners' experience \& capacity, importance of duration, importance of cost, type of construction, complexity, innovation, flexibility, the need to integrate design \& construction, market conditions, and 
uncertainty (Table 3). The reviewers will evaluate such qualitative evaluation criteria by looking into the values of the quantitative factors. Thus, this study determined if the factors derived through the analysis of the construction project post-evaluation reports have any relevance with the evaluation criteria for the project delivery method selection considered in the deliberation process by conducting a survey among construction experts.

Table 3. Quantitative factors affecting the qualitative criteria.

\begin{tabular}{|c|c|}
\hline Delivery method selection criteria through previous studies & Quantitative factors that can affect the delivery method selection criteria \\
\hline Owners' experience \& capacity & Type of road \\
Importance of duration & Volume of traffic \\
Importance of cost & Length of road \\
Type of construction & Number of lanes \\
Complexity & Number of interchanges \& intersections \\
Innovation & Length of bridge \\
Flexibility & Length of tunnel \\
Need to integrate design \& construction & Project duration \\
Market conditions & Project cost \\
Uncertainty & Owners' experience \\
& Project location (downtown or otherwise) \\
& Government debt \\
& Construction business survey index \\
& Rate of rise of consumer prices \\
& Real GDP growth rate \\
\hline
\end{tabular}

For the investigation, a questionnaire survey among 21 experts with experience in ordering, supervision, and CM companies in the construction sector was conducted on the topic of the quantitative factors affecting the qualitative project delivery method selection criteria through previous studies when planning road construction projects. The survey results were analyzed through correlation analysis. In the analysis, the PASW Statistics 18 program was used, and according to the chi-squared test results obtained through the correlation analysis, the factors within the $95 \%$ confidence level, or the significance level of less than 0.05 , were interpreted as meaningful results associated with the qualitative project delivery method selection criteria through previous studies. With respect to the analysis results, as the standard of the "need to integrate design \& construction" item among the existing project delivery method selection criteria varies depending on the situation, there was no correlation with the quantitative factors that was derived from the relevant report (Table 4). In Table 4, "number of origin factors" represents how many items of the qualitative project delivery method selection criteria in the existing laws are associated with the quantitative factors presented in this paper, and if the number of origin factors is 0 , there is no association with the project delivery method selection criteria in the laws.

Table 4. Results of the significance level to the correlation analysis (PASW Statistics 18 program).

\begin{tabular}{|c|c|c|c|c|c|c|c|c|c|c|c|c|}
\hline \multirow[b]{2}{*}{$\begin{array}{l}\text { Quantitative criteria to } \\
\text { be proposed }\end{array}$} & \multicolumn{10}{|c|}{ Conventional delivery method selection criteria } & \multirow[b]{2}{*}{$\begin{array}{l}\text { No. of } \\
\text { origin } \\
\text { factors }\end{array}$} & \multirow[b]{2}{*}{ Results } \\
\hline & \begin{tabular}{|c|} 
Owners' \\
experience \\
$\&$ \\
capacity
\end{tabular} & $\begin{array}{l}\text { Importance } \\
\text { of Duration }\end{array}$ & $\begin{array}{c}\text { Importance } \\
\text { of Cost }\end{array}$ & $\begin{array}{c}\text { Type of } \\
\text { Construction }\end{array}$ & Complexity & Innovation & Flexibility & \begin{tabular}{|c|} 
Need to \\
integrate \\
design \& \\
construction
\end{tabular} & $\begin{array}{c}\text { Market } \\
\text { conditions }\end{array}$ & Uncertainty & & \\
\hline Type of road & - & - & - & 0.002 & 0.031 & - & - & - & 0.029 & 0.007 & 4 & $\mathrm{O}$ \\
\hline Volume of traffic & - & - & - & 0.013 & 0.037 & - & - & - & - & - & 2 & $\mathrm{O}$ \\
\hline Length of road & - & 0.001 & - & 0.001 & - & - & 0.05 & - & 0.05 & 0.017 & 5 & $\mathrm{O}$ \\
\hline Number of lanes & - & - & - & - & - & - & - & - & - & - & 0 & $\mathrm{X}$ \\
\hline $\begin{array}{c}\text { Number of } \\
\text { interchanges\&intersections }\end{array}$ & - & - & 0.012 & - & - & - & - & - & - & 0.029 & 2 & $\mathrm{O}$ \\
\hline Length of bridge & - & 0.004 & - & - & 0.002 & - & 0.048 & - & 0.048 & 0.014 & 5 & $\mathrm{O}$ \\
\hline Length of tunnel & - & 0.001 & - & - & 0.003 & - & 0.04 & - & 0.04 & 0.011 & 5 & $\mathrm{O}$ \\
\hline Project duration & - & 0.006 & - & - & - & - & - & - & 0.006 & - & 2 & $\mathrm{O}$ \\
\hline Project cost & - & - & - & - & 0.023 & - & - & - & - & 0.008 & 2 & $\mathrm{O}$ \\
\hline Owner's experience & 0.026 & - & - & - & - & 0.048 & 0.002 & - & 0.017 & - & 4 & $\mathrm{O}$ \\
\hline Project location & 0.015 & - & - & - & 0.001 & - & - & - & 0.015 & 0.05 & 4 & $\mathrm{O}$ \\
\hline Government debt & - & - & - & 0.05 & - & - & - & - & 0.01 & 0.01 & 3 & $\mathrm{O}$ \\
\hline $\begin{array}{l}\text { Construction business } \\
\text { survey index }\end{array}$ & - & - & - & - & - & - & - & - & 0.001 & - & 1 & $\mathrm{O}$ \\
\hline $\begin{array}{c}\text { Rate of rise in consumer } \\
\text { prices }\end{array}$ & - & - & - & - & - & - & - & - & - & - & 0 & $\mathrm{X}$ \\
\hline Real GDP growth rate & - & - & - & - & - & - & - & - & 0.001 & - & 1 & $\mathrm{O}$ \\
\hline
\end{tabular}

In this regard, among the quantitative factors derived from the construction project post-evaluation reports, type of 
road, volume of traffic, length of road, number of interchanges \& intersections, length of bridge, length of tunnel, project duration, project cost, owners' experience, project location, government debt, construction business survey index, and real GDP growth rate (all the factors except for number of lanes and rate of rise of consumer prices) were found to be correlated to the conventional project delivery method selection evaluation criteria through previous studies (Table 4). These analyzed factors were used for the DT analysis discussed in section 3.3.2.

\subsubsection{Step 2: Survey on the Quantitative Factors Affecting the Project Delivery Method Selection}

A total of 146 road construction cases collected through the construction project post-evaluation reports were analyzed and organized with the 13 quantitative factors affecting road construction project delivery method selection analyzed previously. The effect of each factor on the project delivery method selection was analyzed by applying DT analysis, an AI technique, to the organized dataset. The DT algorithm includes ID3, C4.5, C5.0, CART, and more, and a DT was developed through each algorithm [21]. From these, the C5.0 algorithm was applied because it can deal with different types of data, has a relatively fast processing speed, and can perform an analysis even when a few values may be missing among the factors of the data factor [22].

The C5.0 algorithm was developed by Quinlan, and the DT was configured based on the concept of entropy. It indicates the amount of information that the specific attribute (factor) has, and the structure of the variable for each branch of the DT. The amount of information that the attribute (factor) of the dataset has is calculated based on the information gain theory, and is represented by the following formula [21]. The Gain $(X, A)$ value by the formula is obtained by subtracting the entropy values of the subsets of attribute $A$ from the entropy of the entire dataset, and it is the expected reduction in entropy due to the sorting of $A$. This represents the extent to which the attribute $A$ can gain information, and as this value is higher, it is considered to be located higher on the DT. Fig. (3) is a DT in which the dataset collected in this study is analyzed using the WEKA 3.6 program, and shows that high $\operatorname{Gain}(X, A)$ values such as those of "owner's experience" and "length of tunnel" are located higher on the tree.

$$
\begin{gathered}
\operatorname{Gain}(X, A)=\operatorname{Entropy}(X)-\sum_{v \in \text { Values }(A)} \frac{\left|X_{v}\right|}{|X|} \operatorname{Entropy}\left(X_{v}\right) \\
\left(\text { Entropy }(X)=-\sum_{i=1}^{m} p_{i} \log _{2}\left(p_{i}\right)\right)
\end{gathered}
$$

$X$ is a sample of training examples

$X_{v}$ is samples of attribute A's training examples

$\mathrm{p}_{\mathrm{i}}$ is the proportion of examples in $X$

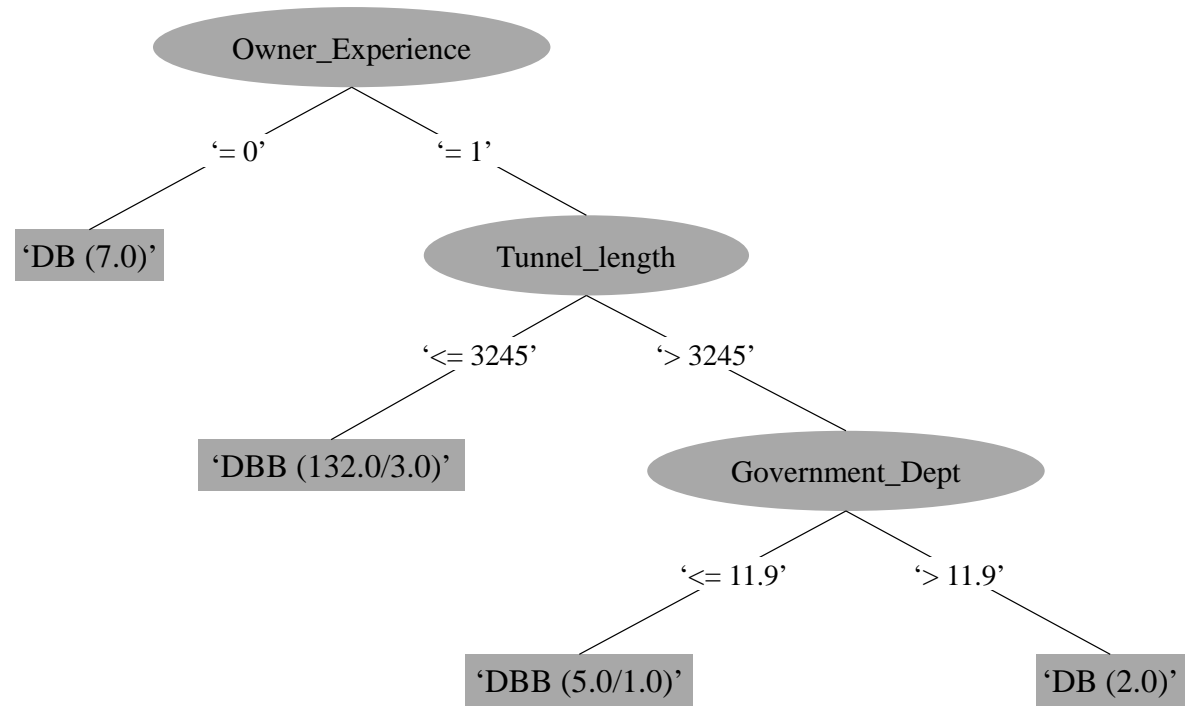

Fig. (3). Sample of decision trees for project delivery method selection (WEKA 3.6 program). 
In other words, the $\operatorname{Gain}(X, A)$ value can be interpreted as the degree to which attribute $A$ has an effect on the target value or weight. Accordingly, in this study, the weights of the quantitative criteria affecting the project delivery method selection through the preceding correlation analysis were calculated by a C5.0 algorithm of the DT analysis after setting the road construction project delivery method as the target value. To obtain the weight of the attribute (factor), the WEKA 3.6 program was used, and the results are shown in Table 5. The analysis results show that the three quantitative factors that have the greatest effects on the project delivery method selection are "owners' experience," "length of tunnel," and "project cost." "Volume of traffic," length of road," "construction business survey index," "number of interchanges \& intersections," "real GDP growth rate," and "project duration" are the factors that were shown to have no effect on the project delivery method selection as their $\operatorname{Gain}(X, A)$ value is 0 .

Table 5. Results of the information gain values of the factors affecting project delivery method selection.

\begin{tabular}{|c|c|c|}
\hline Factors (Attributes) & Information Gain Values & Rank \\
\hline Owner's Experience & 0.18894 & 1 \\
\hline Length of Tunnel & 0.15863 & 2 \\
\hline Project Cost & 0.09241 & 3 \\
\hline Length of Bridge & 0.08632 & 4 \\
\hline Type of Road & 0.07362 & 5 \\
\hline Government Debt & 0.04866 & 6 \\
\hline Project Location & 0.00669 & 7 \\
\hline Volume of Traffic & 0 & - \\
\hline Length of Road & 0 & - \\
\hline Construction Business Survey Index & 0 & - \\
\hline The number of Interchange \& Intersection & 0 & - \\
\hline Real GDP Growth Rate & 0 & - \\
\hline Project Duration & & - \\
\hline
\end{tabular}

\subsection{Calculation of the Project Performance Evaluation Score}

In establishing the CBR system, if the performance resulting from the selected project delivery method can be seen as result values in addition to the retrieval of the project delivery method of similar cases, the decision-making regarding the project delivery method can be effectively supported. To implement this, the performance for each case was derived through the construction project post-evaluation reports analyzed previously. The effects of the project delivery method decision tasks on the project performance results for each case were analyzed for indexation. The project performance that can be derived from the construction project post-evaluation reports includes the rate of increase and decrease compared to the plan of the project costs, the project duration and design duration, the $\mathrm{B} / \mathrm{C}$ ratio, the number of reconstruction works, the number of defects, and the rate of increase or decrease compared to that of the original plan. Of these, the number of reconstruction works and defects delays the construction project duration and is included in the performance of the increase and decrease rate of the project duration compared to the plan. Therefore, it was not taken into account. Furthermore, as the rate of traffic increase and decrease compared to the original plan is a performance included in the $\mathrm{B} / \mathrm{C}$ ratio, it was not considered in this study. In other words, the performance of the construction project was defined by four factors: the project cost achievements, the project duration and design duration compared to the plans, and the $\mathrm{B} / \mathrm{C}$ ratio. These data were then analyzed and organized.

After the foregoing, the influences of the project delivery method decision tasks on the four performance factors were analyzed through an analytic hierarchy process (AHP). AHP analysis is utilized to derive the information preferred by experts through a pair-wise comparison of the evaluation factors or alternatives through a survey. The AHP survey was conducted with a total of 21 construction experts, and among the survey results, only the results determined to have consistency - as when the consistency ratio (CR) value was less than 0.1 - were used in the analysis [23]. The influences of the delivery method decision tasks on the four performance factors of the construction project through the AHP analysis are summarized in Table 6. The AHP analysis results showed that the project delivery method decision tasks had the largest influence on the "construction project cost achievement," with a 0.414 influence value, followed by the $\mathrm{B} / \mathrm{C}$ ratio, construction project duration achievement, and design duration achievement. 
Table 6. Influences of the delivery method decision on the project performance factors.

\begin{tabular}{|c|c|c|c|c|}
\hline Performance Factor & $\begin{array}{c}\text { Construction project cost } \\
\text { achievement vs. the plans (I1) }\end{array}$ & $\begin{array}{c}\text { Construction project duration } \\
\text { achievement vs. the plans (I2) }\end{array}$ & $\begin{array}{c}\text { Construction project design } \\
\text { duration achievement vs. the plans } \\
\text { (I3) }\end{array}$ & $\begin{array}{c}\text { B/C Ratio(I4) } \\
\text { Influence Value }\end{array}$ \\
\hline
\end{tabular}

Of the four performance factors of the construction project, the construction project with a larger performance value of the factor that has a higher influence due to the decision on the project delivery method is considered a case project where the delivery method decision tasks have a good effect on the performance of the construction project. Considering the ratios of the four performance factors of each construction project case and the influences analyzed in Table 6, the effects of the project delivery method decision tasks on the performance of the construction projects can be represented as indices. The index is defined as the Effectiveness of Selecting the project Delivery method for the project Performance Index (ESDPI), and ESDPI 100 refers to the effectiveness for the performance if the influences of the project delivery method decision tasks on the performance factors are the same. Based on this, as the ratio of the four performance values of each construction project changes, the ESDPI changes as well, and the larger the index is, the greater the effect of the project delivery method decision on the performance. The effect, therefore, of the project delivery method decision for each case on the performance can be measured quantitatively through the index (ESDPI). Also, it can be utilized as values to be considered in selecting the project delivery method.

$$
E S D P I=\frac{\sum_{i=1}^{n}\left(x_{i} \times I_{i}\right)}{\frac{1}{n} \sum_{i=1}^{n} x_{i}} \times 100 \quad\left(\sum_{i=1}^{n} I_{i}=1\right)
$$

$l_{n}=$ Influence values of selecting the project delivery method to the performance factors

$\mathrm{X}_{\mathrm{n}}=$ Construction project performance achievements

$$
E S D P I=\frac{\left(x_{1} \times I_{1}\right)+\left(x_{2} \times I_{2}\right)+\left(x_{3} \times I_{3}\right)+\left(x_{4} \times I_{4}\right)}{\left(x_{1}+x_{2}+x_{3}+x_{4}\right) \times \frac{1}{4}} \times 100
$$

$I_{1}=$ Influence value of selecting the project delivery method to the project cost performance

$\mathrm{I}_{2}=$ Influence value of selecting the project delivery method to the project duration performance

$\mathrm{I}_{3}=$ Influence value of selecting the project delivery method to the project design duration performance

$I_{4}=$ Influence value of selecting the project delivery method to the project $\mathrm{B} / \mathrm{C}$ ratio

$x_{1}$ (Construction project cost achievement vs. the plans $)=\frac{\text { Plans Project Cost }}{\text { Actual Project Cost }} \times 100$

$\mathrm{x}_{2}$ (Construction project duration achievement vs. the plans $)=\frac{\text { Plans Project Duration }}{\text { Actual Project Duration }} \times 100$

$\mathrm{x}_{3}($ Construction project design duration achievement vs. the plans $)=\frac{\text { Plans Design Duration }}{\text { Actual Design Duration }} \times 100$

$\mathrm{x}_{4}(\mathrm{~B} / \mathrm{C}$ Ratio $)=\frac{\text { Benefit }}{\text { Cost }} \times 100$

\section{RESULTS}

\subsection{Case Retrieval}

The CBR system was constructed with 146 road construction cases analyzed previously to create a decision-making support system for project delivery method selection with focus on road construction. The value derived through the DT analysis was applied with respect to the attributes and weights of the attributes for similarity calculation (Table 7). The higher the weights allocated to each attribute (factor) were, the greater the influence on the similarity. The information input regarding the current construction project by attribute (factor) in Table 7, and retrieval, make it possible to find the project delivery methods of past construction project cases that are most similar to the current construction project in 
terms of the project delivery method used. The construction project cases of the established dataset have ESDPI values selected through Eq. 3 in section 3.4, respectively, and therefore, two types of information, the selected project delivery method and ESDPI, can be obtained in the retrieved case through the devised CBR system. In the process of the decision-making for the construction project delivery method selection, if the CBR system proposed in this study is applied, not only the project delivery method derived through retrieval but also the ESDPI can be taken into consideration. Thus, it may be able to support effective decision-making.

Table 7. Attributes and weights of CBR.

\begin{tabular}{|c|c|}
\hline Attributes & Weights \\
\hline Owner's experience & 0.18894 \\
\hline Length of tunnel & 0.15863 \\
\hline Project cost & 0.09241 \\
\hline Length of bridge & 0.08632 \\
\hline Type of road & 0.07362 \\
\hline Government debt & 0.04866 \\
\hline Project location & 0.00669 \\
\hline
\end{tabular}

\subsection{Case Adaptation with Illustrative Examples}

In the CBR system that was constructed, the project delivery method and ESDPI derived through the retrieval provides implications different from those of previous studies. This is because unlike in the previous studies that selected the project delivery method to be used considering only the project information at the time that such selection was to be made, the proposed decision-making support system based on CBR can be made considering the effects of the project delivery method decision tasks on the performance of the future project. The CBR system dataset for road construction project delivery method selection established in this study was tested using the myCBR program Fig. (4). Weight of Attributes indicated in Fig. (4) is calculated by Eq. 1. Table 8 shows the results of the input test data to the attributes of CBR for retrieval. The similar case was retrieved from the CBR system that was established to select the project delivery method to be applied to this project with any of the project where "owner's experience" is "Yes," "length of tunnel" is $0 \mathrm{~m}$, "project cost" is 240 billion won, "length of bridge" is 2,000 m, "type of road" is national highway, "government debt" is $20 \%$, and "project location" to the downtown area is "Yes" for the exemplified values. As the cases with the highest degree of similarity that were derived through the retrieval, however, such as Road Project 74 and Road Project 85, have nearly the same degree of similarity (0.95), it is difficult to select between the two project delivery methods (DB and DBB) based only on the similarity. If only the project delivery method results are provided when different project delivery methods are applied to cases with similarities, the resultant value of the CBR system becomes useless because it is impossible to know which project delivery method is most advantageous. The CBR system proposed in this study can support the decision-making for the project delivery method selection in this situation by providing an ESDPI (calculated by Eq. 3.). That is, in the case of Table 8, through a comparison of the ESDPI values of the two cases with the same degree of similarity, DBB, which is the project delivery method of Road Project 85, with a larger ESDPI between DB and DBB, can be determined, and therefore, the CBR system established through this study can support the effective project delivery method selection decisions.

Table 8. Results of illustrative example to CBR.




(Table 8) contd....

\begin{tabular}{|c|c|c|c|c|c|c|}
\hline \multicolumn{7}{|c|}{ Input data to the attributes of CBR for retrieval } \\
\hline Owner's experience & $\begin{array}{l}\text { Length of tunnel } \\
\text { (m) }\end{array}$ & $\begin{array}{l}\text { Project cost (million } \\
\text { won) }\end{array}$ & $\begin{array}{c}\text { Length of } \\
\text { bridge (m) }\end{array}$ & Type of road & $\begin{array}{l}\text { Government debt } \\
\text { (against GDP, \%) }\end{array}$ & $\begin{array}{l}\text { Project location to } \\
\text { the downtown area }\end{array}$ \\
\hline \multicolumn{3}{|c|}{ Length of bridge $(\mathrm{m})$} & \multicolumn{2}{|l|}{1,914} & \multicolumn{2}{|l|}{2,200} \\
\hline \multicolumn{3}{|c|}{ Type of road } & \multicolumn{2}{|c|}{ National highway } & \multicolumn{2}{|c|}{ National highway } \\
\hline \multicolumn{3}{|c|}{ Government debt (against GDP, \%) } & \multicolumn{2}{|l|}{16} & \multicolumn{2}{|l|}{16} \\
\hline \multicolumn{3}{|c|}{ Project location to the downtown area } & \multicolumn{2}{|l|}{ Yes } & \multicolumn{2}{|l|}{ No } \\
\hline
\end{tabular}

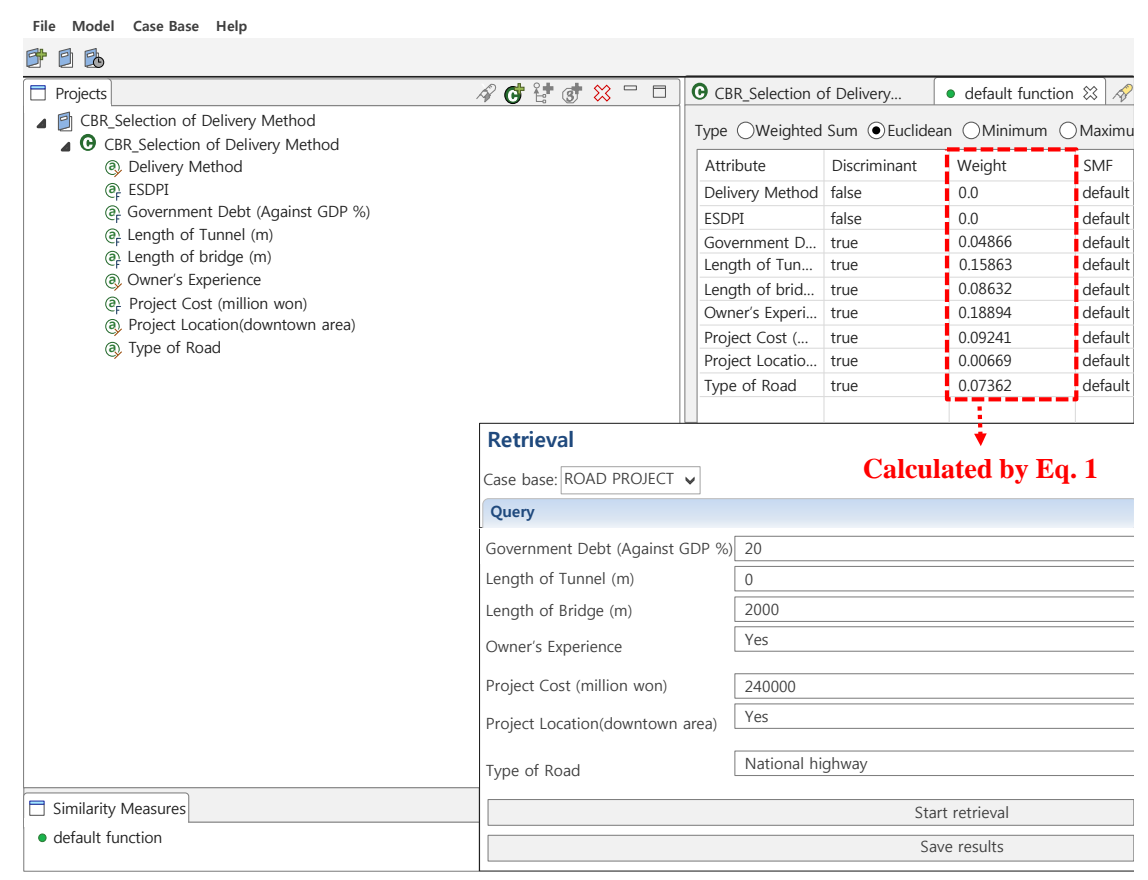

Fig. (4). Input Information to myCBR program.

\section{CONCLUSION}

This study proposed a CBR system that can support the decision-making for the construction project delivery method selection based on a collection and analysis of the 146 construction project post-evaluation reports with focus on road construction cases.

1. Through correlation analysis, the correlation between the conventional project delivery method selection evaluation criteria and the quantitative factors of the selection of the project delivery method proposed in this study were analyzed. In this regard, among the quantitative factors derived from the construction project postevaluation reports, the "type of road," "volume of traffic," "length of road," "number of interchanges \& intersections," "length of bridge," "length of tunnel," "project duration," "project cost," "owners' experience," "project location," "government debt," "construction business survey index," and "real GDP growth rate" were found to be correlated to the conventional criteria.

2. The weights of the quantitative factors analyzed above affecting the decision on the project delivery method to be used were then analyzed through DT analysis. The analysis results showed that the three quantitative factors that have the greatest effects on the decision on the project delivery method to be used are "owners' experience," "length of tunnel," and "project cost."

3. Following this, ESDPI was analyzed and organized by case among 146 road construction projects. After that, a decision-making support system based on CBR for project delivery method selection was constructed using these cases. Then, case adoption with the test data was conducted to show the proposed CBR system using ESDPI.

In this study, the proposed system was devised so that not only the characteristics of the project but also the project performance by project delivery method can be taken into account. Therefore, this study expected to support the decision-making for the project delivery method selection more effectively than the previous studies. As the 
construction project have become larger and more complex, it is increasingly and important to manage the project cost and duration. The proposed system support decision-making for construction project delivery method selection quickly and accurately, so the increased project cost and duration derived from delays of decision-making can be reduced.

For future research, it is necessary to conduct a study on the standards for writing construction project postevaluation reports so as to write these reports with consistency, and to record more information therein. In addition, further research on the performance factors to be considered in the calculation of the ESDPI is needed.

\section{LIST OF ABBREVIATIONS}

$\begin{array}{lll}\text { AHP } & = & \text { Analytic hierarchy process } \\ \text { ANP } & = & \text { Analytic network process } \\ \text { AI } & = & \text { Artificial intelligence } \\ \text { CALS } & = & \text { Continuous acquisition \& lifecycle support } \\ \text { CBR } & = & \text { Case-based reasoning } \\ \text { CPTP } & = & \text { Criteria package technical proposal } \\ \text { DB } & = & \text { Design-build } \\ \text { DBB } & = & \text { Design-bid-build } \\ \text { DDTP } & = & \text { Detailed design technical proposal } \\ \text { DT } & = & \text { Decision tree analysis } \\ \text { ESDPI } & = & \text { Effectiveness of selecting a project delivery method for the project performance index } \\ \text { MLIT } & = & \text { Ministry of Land, Infrastructure, and Transport of the South Korean government }\end{array}$

\section{CONFLICT OF INTEREST}

The authors confirm that this article content has no conflict of interest.

\section{ACKNOWLEDGEMENTS}

This research was supported by a grant (15TBIP-C094465-01) from Technology and Commercialization Support Program funded by the Ministry of Land, Infrastructure and Transport of the South Korean Government.

\section{REFERENCES}

[1] E.A. Choi, B.O. Kim, and S.B. Lee, "A study on the selection criteria for delivery systems of public construction projects in local governments", Korea Inst. Build. Const., vol. 9, no. 5, pp. 113-119, 2009.

[2] C.K. Riesbeck, and R.C. Schank, Inside Case-Based Reasoning., Lawrence Erlbaum Associates: New Jersy, 1989.

[3] D.K. Chua, and P.K. Loh, "CB-contract: case-based reasoning approach to construction contract strategy formulation", J. Comput. Civ. Eng., vol. 20 , no. 5, pp. 339-350, 2006. [http://dx.doi.org/10.1061/(ASCE)0887-3801(2006)20:5(339)]

[4] D.T. Luu, S.T. Ng, and S.E. Chen, "Formulating procurement selection criteria through case-based reasoning approach", J. Comput. Civ. Eng., vol. 19, no. 3, pp. 269-276, 2005.

[http://dx.doi.org/10.1061/(ASCE)0887-3801(2005)19:3(269)]

[5] D.K. Chua, D.Z. Li, and W.T. Chan, "Case-based reasoning approach in bid decision making", J. Constr. Eng. Manage., vol. 127, no. 1, pp. $35-45,2001$. [http://dx.doi.org/10.1061/(ASCE)0733-9364(2001)127:1(35)]

[6] C.T. Hyun, and Y.C. Seo, "A method of selecting delivery systems for public construction projects using the analytic network process", $J$. Arch. Inst. Korea Struct. Constr., vol. 19, no. 7, pp. 211-218, 2003.

[7] K.I. Kim, Y.C. Seo, and C.T. Hyun, "A study on the selection criteria for delivery systems in the large public building projects", J. Arch. Inst. Korea Struct. Constr., vol. 16, no. 4, pp. 79-86, 2000.

[8] I.H. Yu, and K.R. Kim, "Project delivery systems and project performance, an evaluation model for public construction projects", In: The Korea Institute of Construction Engineering and Management Annual Conference, 2007, pp. 41-47.

[9] D.G. Kim, U.K. Lee, and H.J. Lee, "Determining decision-making factors for the selection of contract methods in public construction", J. Korean Inst. Build. Constr., vol. 15, no. 4, pp. 405-412, 2015. [http://dx.doi.org/10.5345/JKIBC.2015.15.4.405]

[10] H. S. Lee, and K. H. Kim, "An study about improvement idea for performance-based project delivery system based on client's role", In: The Architectural Institute of Korea Structure \& Construction Conferenece, vol. 29. 2009, no. 1, pp. 593-596. 
[11] S.K. Lee, and Y.S. Jung, "Project performance comparison based on different types of project delivery system", In: The Korean Institute of Building Construction Conference, 2011, pp. 207-209.

[12] B. Rajagopalan and R. Krovi, "Benchmarking data mining algorithms", J. Database Manage., vol. 13, no. 1, pp. 25-35, 2002. [http://dx.doi.org/10.4018/jdm.2002010103]

[13] M. Ida, and E. Malihe, "Comparing decision tree method over three data", Int. J. Stat. Probab., vol. 3, no. 3, pp. 147-156, 2014. [http://dx.doi.org/http://dx.doi.org/10.5539/ijsp.v3n3p147]

[14] A. Aamodt, and E. Plaza, "CBR: foundational issues, methodological variations and system approaches", AI Commun., vol. 7, no. 1, pp. 39-59, 1994.

[15] Y.M. Goh, and D.K. Chua, "Case-based reasoning for construction hazard identification: Case representation and retrieval", J. Constr. Eng. Manage., vol. 135, no. 11, pp. 1181-1189, 2009. [http://dx.doi.org/10.1061/(ASCE)CO.1943-7862.0000093]

[16] S.H. Ji, M.S. Park, and H.S. Lee, "Case adaptation method of case-based reasoning for construction cost estimation in Korea", J. Constr. Eng. Manage., vol. 138, no. 1, pp. 43-52, 2012.

[http://dx.doi.org/10.1061/(ASCE)CO.1943-7862.0000409]

[17] R. Jin, S.W. Han, C.T. Hyun, and Y.W. Cha, "Application of case-based reasoning for estimating preliminary duration of building projects", J. Constr. Eng. Manage., vol. 142, no. 2, 2016. [http://dx.doi.org/10.1061/(ASCE)CO.1943-7862.0001072]

[18] R. Kabra, and S. Bichkar, "Performance prediction of engineering students using decision trees", Int. J. Comput. Appl., vol. 36, no. 11, pp. 8-12, 2011.

[19] K.S. Kim, and J.H. Park, "A survey of applications of artificial intelligence algorithms in ecoenvironmental modelling", J. Korean Soc. Environ. Eng., vol. 14, no. 2, pp. 102-110, 2009. [http://dx.doi.org/http://dx.doi.org/10.4491/eer.2009.14.2.102]

[20] H.S. Moon, K.M. Cho, T.H. Hong, and C.T. Hyun, "Selection model for delivery methods for multifamily-housing construction projects", J. Manage. Eng., vol. 27, no. 2, pp. 106-115, 2011 [http://dx.doi.org/10.1061/(ASCE)ME.1943-5479.0000038]

[21] J. Han, M. Kamber, and J. Pei, DATA MINING Concepts and Techniques., Elsevier Inc.: Massachusetts, 2012.

[22] B.R. Patel, and K.K. Rana, "A survey on decision tree algorithm for classification", Inter. J. Eng. Devel. Res, vol. 2, no. 1, pp. 1-5, 2014.

[23] T.L. Saaty, "Relative measurement and its generation in decision making why pairwise comparisions are central in mathematics for the measurement of intangible factors the analytic hierarchy/network process", J. RACSAM, vol. 102, no. 2, pp. 251-318, 2008.

(C) Yoon et al. ; Licensee Bentham Open

This is an open access article licensed under the terms of the Creative Commons Attribution-Non-Commercial 4.0 International Public License (CC BY-NC 4.0) (https://creativecommons.org/licenses/by-nc/4.0/legalcode), which permits unrestricted, non-commercial use, distribution and reproduction in any medium, provided the work is properly cited. 